\title{
Representação como processo: a relação Estado/sociedade na teoria política contemporânea
}

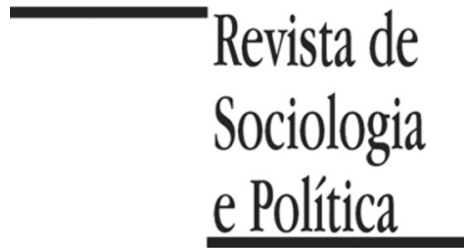

DOI: $10.1590 / 1678-987314225011$

\author{
Debora Rezende de Almeida
}

\begin{abstract}
RESUMO
O conceito de representação política vem passando por uma reformulação profunda na teoria política contemporânea, motivada pela constatação empírica do papel da sociedade civil como representante político. O reconhecimento da representação no campo societal impõe novos desafios à teoria democrática, alguns dos quais serão discutidos neste trabalho. Primeiro, o artigo propõe repensar o conceito de representação política, baseado em duas ideias principais, a saber: (i) a representação é vista como um processo e como uma construção; (ii) a fim de compreender o potencial democratizante dessas transformações, o artigo reinterpreta os critérios de legitimidade democrática da representação. Sugere-se que a legitimidade é construída durante a representação e não apenas obtida por meio da autorização eleitoral. Isso não requer abandonar a tensão entre representante e representado, tampouco os mecanismos de autorização e accountability, mas repensá-los a partir de um processo contínuo e distinto entre os variados exemplos de representação da sociedade. Finalmente, o trabalho argumenta que as práticas de representação da sociedade civil nas instituições de cogestão de políticas públicas no Brasil trazem contribuição distinta à teoria da representação. Elas colocam em destaque a importância de distinguir-se os atores do Estado e da sociedade a partir da consideração da atividade representativa e autoridade mobilizada, e não primariamente a partir de sua esfera de atuação. Diferentemente dos espaços informais de influência, os atores coletivos que participam dessas instituições ganham uma autoridade posicional, quando investidos com o poder legal de deliberação e decisão pelo Estado. Ademais, as instituições de cogestão introduzem novos elementos para avaliar-se o processo de autorização, prestação de contas e responsividade, não tematizados pela literatura internacional.
\end{abstract}

PALAVRAS-CHAVE: teoria política; representação; democracia; legitimidade; instituições de cogestão.

Recebido em 29 de Dezembro de 2012. Aprovado em 09 de Abril de 2013.

\section{Introdução ${ }^{1}$}

\footnotetext{
${ }^{1}$ Agradeço aos pareceristas anônimos da Revista de Sociologia e Política por suas observações e contribuições valiosas. Este artigo apresenta uma discussão teórica da minha tese de doutorado, defendida no Departamento de Ciência Política da Universidade Federal de Minas Gerais (UFMG), a qual recebeu a Menção Honrosa do Prêmio Capes de Teses, Edição 2011.
}

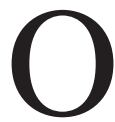
Brasil transformou-se, ao longo dos últimos 20 anos, em um país democrático e com uma impressionante diversidade de práticas participativas, as quais vinculam Estado e sociedade no processo de formulação de políticas públicas e redistribuição de bens e serviços (Avritzer 2009). As experiências mais notáveis são o orçamento participativo e os conselhos de políticas, cujas práticas e modelos de participação inspiram a criação de instituições em diferentes lugares e o desenvolvimento de estudos sobre o significado da democracia contemporânea. Até recentemente, as principais chaves analíticas sobre as experiências de inclusão da sociedade civil, tanto na literatura brasileira como na internacional, focavam a teoria participativa e/ou deliberativa. Na última década, as pesquisas registraram uma mudança interessante em direção ao papel representativo dos atores sociais (Avritzer 2007; Lavalle, Houtzager \& Castello 2006; Lüchmann 2008; Saward 2011; Vieira \& Runciman 2008; Urbinati \& Warren 2008). Embora a vocalização pública de interesses seja uma prática comum das ações de protesto e das expressões da ação coletiva, apenas recentemente a teoria política passou a denominá-la de representação (Lavalle 2011). 
É importante lembrar que, apesar de o debate no país ecoar a discussão teórica internacional, na prática a representação da sociedade civil ganha proporções distintas. A participação, no Brasil, é canalizada para dentro do sistema político a partir da inserção de organizações civis e atores coletivos no processo de formulação de políticas públicas. Esses atores não recebem apenas o reconhecimento como porta-vozes da sociedade, mas faculdades e investidura regulamentadas (idem). Diferentemente dos modelos internacionais baseados na influência informal dos atores sociais, as instituições que conectam Estado e sociedade são parte de um processo de pluralização institucional da democracia brasileira. Para além das questões centrais na literatura sobre representação nesse novo contexto, tais como o que significa representar e quais são os fundamentos da legitimidade da representação, a institucionalização que dá início com a redemocratização no país coloca novos desafios teóricos.

Este artigo tem o objetivo central de responder a essas duas questões, referentes à definição da representação e aos fundamentos de sua legitimidade, a partir da consideração da natureza diferenciada do exercício representativo nas sociedades contemporâneas. Tal investigação divide-se em três seções. A primeira apresenta uma redefinição do conceito de representação baseada na leitura crítica de intérpretes recentes da teoria política, principalmente Nadia Urbinati (2006) e Pierre Rosanvallon (2009). Propõe trazer para o centro do debate duas características da representação que estão presentes nos teóricos que repensam o conceito, a saber, a ideia de que a representação é um processo que se desloca continuamente no tempo e no espaço e está em permanente construção. Representar envolve distintos atores e arenas do Estado e da sociedade, os quais precisam manter interação contínua com os representados. Nesse sentido, é um fenômeno ao mesmo tempo societal e institucional.

A segunda parte discute os fundamentos da legitimidade democrática. Embora Urbinati e Rosanvallon tenham introduzido, por caminhos distintos, a ideia de representação como processo e construção, os autores reduzem a atividade política da sociedade às noções de julgamento político e/ou influência indireta. Consequentemente, não tratam adequadamente do problema da legitimidade da representação da sociedade, uma vez que o papel desses atores é de aproximação ou mesmo contestação entre suas ideias e as decisões estatais. Este artigo defende que a compreensão processual da representação implica um deslocamento da ideia de legitimidade como ato fundacional, a saber, a autorização eleitoral, para situá-la no processo representativo. A legitimidade da representação está baseada em uma relação de mão dupla que envolve não apenas a capacidade do representante expressar distintos interesses, mas também do representado reconhecer a legitimidade desses atos. $\mathrm{O}$ trabalho discute as dificuldades de operacionalização desse ideal nas experiências de representação da sociedade civil, haja vista a ausência de controle institucionalizado e de definição de quem são os constituintes. Propõe uma leitura do processo de autorização, prestação de contas e responsividade que não envolve exclusivamente a dinâmica eleitoral.

A terceira seção entra no universo das instituições de cogestão e/ou controle social, doravante (ICGs) - termo utilizado por Lüchmann (2011). A discussão apontará que as ICGs colocam em evidência a flexibilização de fronteiras entre Estado e sociedade e a importância de romper-se com a diferenciação espacializada entre esses dois polos da atividade política - dentro e fora das instituições estatais - dando ênfase aos tipos de atividade e autoridade dos atores. A dimensão espacial deixa de ser uma característica que define a priori a representação e a participação do Estado ou da sociedade, embora tenha im- 
pacto na autoridade exercida pelos atores sociais nos diferentes arranjos representativos. Desse modo, a seção apresenta as diferenças entre a autoridade do Estado e da sociedade. Em seguida, mostra a distinção entre as experiências formais e informais de representação societal em termos da autoridade mobilizada. A partir de revisão de Saward (2011), o artigo defende que as ICGs superam a transição eventual e não formal de atores para a esfera do Estado. Além da sociedade civil possuir uma autoridade (an authority), construída a partir de um saber prático ou relacionado à vivência com o problema ou política, ela recebe reconhecimento direto pelo Estado. Os atores sociais, nessas instituições formais, ganham um grau de in-ness, de autoridade posicional (in authority), quando investidos do poder legal de decisão e deliberação pelo Estado. Por autoridade posicional dos atores da sociedade civil, refiro-me ao exercício de voz e voto dentro das ICGs, o qual é especificado nos normativos que regulam o seu funcionamento a partir do poder deliberativo desses espaços.

Com relação ao processo de legitimação, as ICGs introduzem novas questões para o debate. Primeiro, o processo de autorização nessas instituições é menos fluido e indeterminado. Apesar de limitado, tendo em vista as regras que delimitam quem é incluído ou excluído do processo de autorização, é possível afirmar que é distinto da simples apresentação voluntária de atores para participar. Segundo, assim como nos processos informais, o relacionamento entre representantes e a pluralidade representada está baseado na possibilidade de justificação pública e na interação entre atores e arenas ao longo do tempo. Todavia, a relativa proximidade com os "afetados" e o fato de os representantes nas ICGs geralmente pertencerem a uma determinada policy community, pode contribuir para relações mais diretas de prestação de contas. Por fim, estão em estreita conexão com os atores estatais, que podem servir como controle e são cruciais para a sua efetividade deliberativa.

Entender as especificidades da representação da sociedade civil é importante para não cairmos em uma avaliação determinista de impossibilidade da representação democrática desses atores, devido à ausência da relação tradicional entre um mandante que autoriza um agente a agir em seu nome. Ademais, a análise empírica sobre os potenciais democratizantes das ICGs e seus efeitos na representação política depende dessa compreensão normativa sobre o que define uma representação democrática.

\section{A reformulação do conceito na teoria democrática contemporânea}

A atual notoriedade do conceito de representação na teoria política vem acompanhada de uma mudança na forma de compreender o fenômeno. Apesar de amplamente discutida na literatura, a representação política geralmente esteve associada às tendências pluralistas e institucionalistas, que reduziram o debate ao tema do governo representativo e à lógica da representação nas esferas do Estado (Araujo 2009; Knights 2009; Lavalle \& Araujo 2008; Vieira \& Runciman 2008). Já as pesquisas recentes extrapolam os estudos sobre partidos, parlamentos e regras eleitorais para focar as transformações da representação, tanto do ponto de vista das instituições tradicionais, quanto das novas instituições e práticas de representação que colocam lado a lado Estado e sociedade na deliberação de políticas públicas. O surgimento e a constatação empírica de formas de representação não-eleitorais colocam vários desafios teóricos. Esta seção tratará da redefinição do conceito, com destaque para duas características consideradas centrais para compreender a pluralidade da 
${ }^{2}$ No livro de 2006, Urbinati enfatiza que é necessário trazer a ideia de soberania para dentro do domínio do julgamento e opinião, ou seja, estes são fatores da soberania, não seus substitutos (Urbinati 2006, p. 106). Recentemente, esta diarquia aparece com mais força. A autora parece indicar que a vontade soberana se expressa em momentos eleitorais intermitentes e o julgamento político se expressa na contínua influência e poder informal dos cidadãos em relação às instituições representativas (Urbinati 2011, pp. 25-26).

\footnotetext{
${ }^{3}$ Aqui Urbinati está indo de encontro à tese hobbesiana, segundo a qual a representação, por ser um ato de criação de uma unidade que não existe antes do pacto, não tem compromisso com a vontade dos indivíduos. Para Hobbes, é a unidade do representante que torna a pessoa una. Ao contrário dos autores parlamentares que defendiam que a representação deve se dar à imagem e semelhança da população, Hobbes sustenta um poder absoluto, no qual o representante age por si mesmo (Skinner 2005, p. 173).
}

representação na contemporaneidade: a dimensão processual e construtiva da representação. Os principais autores mobilizados são Nádia Urbinati e Pierre Rosanvallon.

O ponto de partida de Urbinati $(2006 ; 2011)$ é a restrição da representação em torno das questões de autorização e accountability. Inspirada em Condorcet, teórico da Revolução Francesa, Urbinati sugere a diversificação e a extensão das temporalidades e dos modos de expressão da vida política a fim de reconciliar o conceito de representação com a democracia (Avritzer 2007; Rosanvallon 2009). A "soberania complexa" é compreendida como um processo de interação contínua entre o povo e representantes, expressa por meio do voto, mas também em diversas temporalidades, como referendo, censura e na formulação da Constituição. Nessa visão, a soberania é uma construção histórica e a eleição é uma das múltiplas dimensões da representação e da relação entre Estado e sociedade civil. O povo precisa ser constantemente recriado e a relação entre governantes e governados não é passiva.

A maneira como Urbinati sugere repensar o conceito de soberania popular, tal qual sugerido por Rousseau, já foi trabalhada em diferentes textos (Araujo 2009; Avritzer 2007; Faria 2010; Loureiro 2009). Importa, aqui, destacar sua crítica à noção de soberania como alienação de direitos e ato único da vontade. Para Avritzer (2007, p. 452), a autora supera a visão rousseauniana de soberania como ato da vontade ao substituí-la pela noção de julgamento político. Este trabalho defende que não se trata de uma mera substituição, mas de uma interpretação da soberania a partir de dois componentes, a vontade e o julgamento político $^{2}$. A eleição, desse modo, não é um ato de transferência da soberania, mas uma vontade expressa em um determinado momento. A autorização não é uma substituição ou submissão da participação, na medida em que os indivíduos mantêm seu poder de formular julgamentos, ideias e opiniões (Urbinati 2006, p. 104). A legitimidade da democracia representativa depende tanto de eleições regulares e livres quanto da ativação de uma comunicatividade corrente entre a sociedade civil e política.

Nessa leitura, a representação tem uma natureza intrinsecamente dual. Por um lado, transmite a ideia de agir no lugar do outro como agente autorizado, por outro, a noção de que é um processo de criação de uma unidade que não existia antes. A dualidade da representação reclama, de acordo com Urbinati (2011), características também duais, uma ativa e outra passiva. A representação depende tanto da vontade que autoriza o representante a agir em nome de alguém quanto do julgamento político ou o monitoramento do representado ${ }^{3}$ para dar vida a essa criação. Vontade e julgamento, presença imediata (por meio do voto) e presença mediada (liberdade de expressão e associação) estão entrelaçados na sociedade.

O dualismo entre Estado e sociedade é superado, conforme o primeiro precisa ser constantemente recriado e dinamicamente ligado à sociedade, a fim de passar leis. Para a autora, as múltiplas fontes de informação, comunicação e influência que cidadãos ativam por meio da mídia, movimentos sociais e partidos políticos, não são acessórios, mas constitutivos da representação política. A soberania popular, nessa interpretação, é fonte de tensão endógena entre o poder institucionalizado do Estado e extrainstitucionalizado da sociedade. A democracia representativa começa com eleições, mas desenvolve-se para além delas, incluindo tanto a participação quanto a representação não eleitoral exercida por atores sociais. A diferença dessa última em relação à representação eleitoral diz respeito à ausência de um poder impositivo "authoritative po- 
(idem).

Urbinati contribui para apresentar uma teoria da representação democrática que não está confinada ao governo representativo ou suas instituições tradicionais, englobando a representação não eleitoral da sociedade civil, principalmente no artigo de 2011, como expressão do julgamento político. A sociedade civil, porém, mantém um poder negativo de influenciar, investigar e censurar. O poder é negativo por duas razões: tem a função de parar, controlar ou mudar um dado curso de ação dos representantes eleitos; e pode ser expresso por canais diretos de participação, como referendo e recall, e pela participação indireta e informal, por meio de fóruns sociais, movimentos, associações civis, mídia e demonstrações de rua.

Uma das contribuições de Urbinati é a retomada da representação como central para a política democrática. Diante da utopia de uma sociedade participativa em todos os momentos e assuntos que tocam o indivíduo, a política precisa ser pensada como atividade indireta, a partir da lente da representação. Igualmente, é relevante sua compreensão negativa da soberania, no sentido de que a sociedade não governa a si própria, mas também não perde o controle da política representativa. Porém, um problema que precisa ser superado refere-se ao modo de integrar as novas formas de representação da sociedade civil. Para além do julgamento político expresso, por exemplo, na revisão de leis ou em referendos, a participação dos afetados pela política no processo decisório é uma das dimensões que precisa ser tematizada (Avritzer 2012). Em seu trabalho, a sociedade apenas responde às ações da representação institucionalizada e tem uma atitude passiva ou não ativa nas decisões. Ademais, embora proponha uma circularidade entre julgamento público e representantes eleitos, a autora acaba por conceder um peso crucial aos partidos políticos, na unificação de interesses e ideias da sociedade (Loureiro 2009).

Apesar desses limites, é importante prestar atenção à sua contribuição para a discussão sobre soberania e representação. Para Araujo (2009, p. 55), Urbinati não estabelece uma separação fixa entre dois polos - Estado e sociedade na qual a representação precisa encaixar-se, conforme fórmula tradicional do liberalismo. É a representação que cinde o espaço social, produz e reproduz essa cisão entre Estado e sociedade. Essa noção dinâmica da representação como atividade que opera a mediação entre as diversas parcialidades da vida social e a política é central para a compreensão da representação política como ato de manifestação da soberania. Conforme expresso no título, Urbinati (2006) sugere pensar a representação como um processo político, contrariamente ao modelo estático e privatista do contrato, que a confinou a um relacionamento entre representante eleito e representado (idem, p. 29).

Rosanvallon (2008) também percebe o ato de votar como parte do poder positivo, e as ações da sociedade, ou contra-poderes, no sentido de vigiar, sancionar, impedir e julgar, como constituintes do poder negativo do povo. As ações da sociedade produzem um conjunto de efeitos, e não necessariamente uma autoridade formal ou decisões explícitas que poderiam ser qualificadas

${ }^{4}$ Enquanto Nadia Urbinati trabalha com o registro da teoria política, buscando um modelo normativo para pensar o governo representativo, Rosanvallon aproxima-se da teoria social, na medida em que a representação como políticas. Apesar da semelhança com Urbinati ${ }^{4}$ no que tange à percepção de um poder negativo da sociedade, não há, no pensamento do autor, uma busca por um modelo de representação democrática, no qual as eleições operam o papel de unificação, mesmo que temporária. A visão processual da representação do teórico francês está marcada por uma coexistência contraditória, onde a desconfiança da sociedade exerce um papel democrático 
só faz sentido se pensada ao longo do tempo e a partir de sua constante reconfiguração.

${ }^{5}$ Para uma discussão dos problemas da desconfiança para a democracia, ver crítica de Urbinati (2010).

\footnotetext{
${ }^{6} \mathrm{O}$ apelo à imparcialidade está presente nas agências reguladoras, conselhos técnicos e comissões, por serem considerados mais objetivos e aptos à busca da unanimidade alcançada de modo imparcial. Já o principal exemplo da reflexividade são as Cortes Constitucionais, que têm o papel de multiplicar os enfoques parciais e plurais do bem comum. Destacam o papel reflexivo da democracia, contrário ao distanciamento presente no ideal de imparcialidade.
}

e de resistência em relação aos poderes constituídos. Práticas consideradas apolíticas e a desconfiança do povo podem ajudar na geração de decisões que estão em maior sintonia com princípios democráticos ${ }^{5}$. Nesse ponto, o autor argumenta que a crise da representação não é uma característica recente, mas um qualificador que acompanhou as democracias ao longo do tempo. A diferença atual estaria na forma de a sociedade exprimir o descontentamento e a autocrítica do processo representativo.

Para além das ações de desconfiança da sociedade, Rosanvallon (2009) apresenta três tipos de legitimidade em ascensão no mundo contemporâneo, a fim de lidar com as distintas formas de representação. Para cada tipo de legitimidade, ligadas à ideia de imparcialidade, reflexividade e proximidade, Rosanvallon elenca um conjunto de instituições que teriam o papel de expressá-las ${ }^{6}$. Para os fins deste trabalho, importa ressaltar sua visão sobre as figuras de proximidade, diretamente relacionadas ao governo representativo e à atuação da sociedade. A legitimidade de proximidade não está vinculada a nenhum tipo especial de instituição, mas a um conjunto de expectativas sociais concernentes ao comportamento dos governantes no sentido de tornarem-se mais próximos dos cidadãos (idem, p. 35). As diferentes manifestações e instituições da sociedade civil são percebidas como parte do que designa de "democracia de interação". Existem duas funções políticas da democracia de interação: um trabalho de justificação - confrontação de explicações do poder com as intervenções da sociedade - e um intercâmbio de informações entre o poder e a sociedade. (idem, pp. 300-301).

Embora não seja possível descrever com minúcias a argumentação do autor sobre o papel das diferentes figuras de legitimidade, é possível destacar que a sociedade civil também tem um papel indireto na sua formulação. Ou seja, a sociedade exerce seja a pressão e vigilância sobre os atos do governo, seja a qualificação dos seus atos por meio do provimento de informações. De qualquer maneira, é importante sua visão ampliada do conceito de político, que extrapola as dimensões da política institucionalizada. Tendo em vista os limites do momento eleitoral para dar voz a um povo que só existe em sua forma instantânea e evanescente, Rosanvallon advoga uma "representação permanente", marcada pelo constante embate entre as manifestações da sociedade - de desconfiança e insatisfação com as políticas do governo representativo - e a política institucionalizada.

A temporalidade estendida da representação em Rosanvallon (idem) e o reconhecimento da permanente tensão entre as distintas legitimidades têm como consequência a crítica à separação moderna entre o arranjo institucional e a sociedade. Voltar a uma leitura da representação como circulação (Urbinatti 2006; 2010; 2011) ou como processo permanente (Rosanvallon 2006; 2009) pode ajudar a pensar que os fundamentos da legitimidade da representação estão nessa capacidade constante de operar a mediação entre os dois polos, para além dos momentos de suposta unificação eleitoral. Essa leitura está presente em distintos autores da contemporaneidade. Embora não seja possível discorrer sobre as várias propostas em ascensão, é possível afirmar que há, em comum nesses projetos, a tentativa de desvencilhar o conceito de representação de uma visão estática, na qual o mesmo é visto como um fato ou propriedade de um determinado corpo coletivo ou estrutura. A ideia de que representar é um processo político, um projeto aberto e infinito, é o que une diversos autores (Bohman 2012; Dryzek 2000; Rosanvallon 2009; Saward 2010; Urbinati 2006; Young 2000). 
${ }^{7} \mathrm{O}$ exemplo dado pelo autor, geralmente, se refere à pintura de uma paisagem, a qual o pintor é incapaz de replicá-la, criando no quadro uma representação da mesma.
A dimensão construtiva é parte complementar dessa compreensão processual da representação. Essa visão implica fugir da análise unidirecional, com foco apenas no representante e sua capacidade de agir e ser responsivo. É preciso olhar para as diferentes partes e momentos do processo representativo, dando ênfase ao papel ativo do representado e às disputas em torno do que se representa. A dimensão construtiva da representação clama por uma visão do representado constituído ao longo do tempo, na qual o "constituinte" é fluido e dinâmico. Ankersmit (2002) e sua leitura estética do conceito defende a dimensão interpretativa da representação. Para o autor, não existe um interesse determinado do que representar ou uma visão unificada do representado, visto que esse também é criado pela representação. $\mathrm{O}$ autor critica a concepção restrita e ingênua do conceito em termos da relação principal-agent, tendo em vista que os interesses dos eleitores não são coesos, tampouco são expressos ou dados no momento eleitoral. Ao emprestar do mundo da arte a ideia que qualquer forma de representação nunca é simplesmente uma cópia de uma realidade externa pré-existente ${ }^{7}$, mas sempre uma criação de algo novo, Ankersmit alerta para o permanente estado de tensão entre representantes e representados.

Partindo do pressuposto de que a literatura sobre representação concedeu pouco espaço para a discussão do representado, Saward (2010) defende que a representação deve ser pensada como uma atividade. Tendo em vista que é impossível romper com a distância entre esses dois polos - representante e representado - o conceito de representação deve beneficiar-se de uma noção mais dinâmica e plural da política, na qual as questões "quem representa" e "o que está sendo representado" estão, frequentemente, em construção. Nesse sentido, não apenas a definição sobre o que é o "povo" está em disputa, mas também sobre quem é o agente da representação.

É importante lembrar que a leitura da representação como fenômeno dinâmico já estava presente no livro clássico de Pitkin (1967), quando a mesma define-a como uma atividade criativa, um "agir substantivo por outros". Como um agir, a representação envolve necessariamente a sobreposição de atividades, a pluralidade de arenas e de públicos. "Political representation is primarily a public, institutionalized arrangement involving many people and groups, and operating in the complex ways of large-scale social arrangements. What makes it representation is not any single action by any one participant, but the overall structure and functioning of the system, the patterns emerging from the multiple activities of many people" (idem, p. 221-222; grifos nossos).

Mais à frente, a autora aponta outros modos de representação, descritiva e simbólica, e distintos agentes que exercem representação, como oficiais do Estado, grupos de interesses, lobistas, pessoas que agem perante agências governamentais. De acordo com Wampler (2012, p. 673), Pitkin apresenta-nos um caminho para teorizar onde e quando os cidadãos podem agir como participantes, representantes e representados. Não obstante, o último capítulo do livro acaba por dar atenção a um tipo específico de ação - falar em nome de outros em um contexto institucional estabelecido. Nessa conclusão, a autora parece diluir a pluralidade estabelecida no começo de sua obra, quando constatou o paradoxo inescapável e inerente da representação - tornar presente o ausente. A contribuição da teoria democrática contemporânea vai na direção de pensar outros modos de ação em que o representante mereça ser chamado de representativo e, portanto, recupera o aspecto contínuo e plural do conceito, no qual é difícil estabelecer uma unidade. 
A partir dessas referências, propõe-se acentuar o caráter processual e construtivo da representação a fim interpretar as potencialidades e limites da representação da sociedade civil. A representação, desse modo, é uma atividade que se desloca continuamente no tempo e no espaço e envolve distintos atores e arenas, do Estado e da sociedade. Nesse processo, a definição do que é representado e quem representa está sempre em disputa e construção. Deve-se lembrar que o conceito de representação como relacionamento já está presente na obra de Young (2000). Para ela, a representação não é uma relação de substituição ou identidade com o representado, na qual ele ou ela está presente em sua ausência. Antes, é um relacionamento diferenciado entre atores engajados em um processo diferido no tempo e no espaço. Depende de mediação e conexão dos constituintes uns com os outros e destes com seus representantes (idem, p. 127). Nesse relacionamento, a sociedade civil tem um papel importante na consolidação e expressão de perspectivas sociais. As principais funções da sociedade são a oposição e a accountability dos governantes, a influência sobre a política pública e a possibilidade de mudar a sociedade por meio das ações da própria sociedade (idem, pp. 174-180). Contudo, a esfera pública concebida como espaço plural e contínuo mantém-se como espaço privilegiado de atuação da sociedade. A autora chega a apresentar uma discussão sobre a democracia associativa e os elos entre associações e o processo decisório do Estado, mas o problema da accountability da própria sociedade civil não chega a ser tematizado. Frente ao fenômeno crescente de flexibilização das fronteiras e trânsito de atores nas diferentes arenas estatais e societais, esse é um tema que precisa ser discutido, como se verá nas próximas seções.

Para além dos problemas de construção da legitimidade que serão abordados a seguir, vale lembrar que a fluidez do conceito traz consigo o risco de associar qualquer expressão pública com representação, diluindo seu significado ou as diferenças entre os tipos de representação. Saward (2010), por exemplo, ao defender o deslocamento da ideia da representação como um fato ou qualidade fixa do Estado para a visão de que ela é um evento, propõe olhar para as demandas representativas ("representative claim"). A questão é que o autor acaba englobando em qualquer forma de iniciativa cidadã uma expressiva forma de representação ou do que chama de "autorrepresentação". Não fica claro qual é a diferença entre participação e autorrepresentação. A noção trabalhada por Saward $(2006 ; 2008)$, de que a pessoa é ao mesmo tempo participante, representante e representado, parece mais propícia para lidar com a pluralidade e sobreposição de funções. Nas instituições de cogestão do Brasil, essa dimensão parece muito clara. Um conselheiro de política, por exemplo, é ao mesmo tempo participante de uma organização da sociedade civil, participante do conselho, representante da organização no conselho e, ao mesmo tempo, é representado por outras pessoas e discursos proferidos nesse espaço.

Ademais, para os teóricos políticos preocupados em eliminar o caráter ambíguo da representação, sua fluidez e indeterminação pode transformar o conceito em algo vazio e sem nitidez. Todavia, é importante lembrar do alerta de Pitkin de que representar envolve um paradoxo. O sentido construtivo da representação mostra que a unidade que pode ser obtida por meio da representação democrática será sempre sujeita a disputas dentro dos termos propostos para esse sistema. Reconhecer que a representação é um processo e uma construção, que envolve distintos atores e mobiliza diferentes concepções de legitimidade não é a mesma coisa que dizer que ela é sempre democrática. 


\section{Repensando os fundamentos da legitimidade democrática}

A visão permanente e processual da representação demanda como complemento a discussão sobre os fundamentos de sua legitimidade democrática. Ao deslocar a avaliação da legitimidade exclusivamente do ato fundacional da representação, a saber, a autorização, e situá-la no processo é preciso perguntarse quais são a bases para se avaliar quais são as bases para a análise da representação da sociedade civil. Desse modo, é importante lembrar a natureza dual da representação que envolve relação entre ambas as partes - representante e representado - e também criação de uma unidade que não existia antes, tal qual exposto por Urbinati. Para os teóricos da representação nas esferas do Estado, a legitimidade dos representantes, como criadores da unidade, está dada no momento de sua constituição. A autorização eleitoral permite a expressão livre e igualitária da vontade dos indivíduos na fundamentação do poder. Na medida em que o voto expressa tanto a concordância com o método que seleciona o representante, quanto com os resultados da política, a autorização gera também um senso de obrigação política (Manin 1997, p. 85). No que se refere à relação entre as partes, os sujeitos têm condições de avaliar o quanto as decisões de um governo aproximam-se de seus interesses em momentos institucionalizados de controle - avaliação prospectiva e retrospectiva realizada a partir do voto.

Os limites do controle vertical e das expectativas democráticas colocadas nas eleições não são negligenciáveis. De acordo com Przeworski, Stokes e Manin (1999), o voto pode ser visto mais como promotor da democracia eleitoral, do que como verdadeiro controle vertical do representante. Outrossim, democracias que obedecem a requisitos procedimentais democráticos podem não produzir resultados substantivos - igualdade econômica e governança $a c$ countable (Fox 2000). O que pressupõe considerar que o casamento entre processos e resultados é contingente e que a accountability é sempre um processo imperfeito e dependente da interação entre controles verticais e horizontais e diferentes modos de representação. Não obstante esses limites, é preciso reconhecer que, em última instância, a todos é dada a oportunidade de influenciar a atividade representativa. Surgem dois problemas diferentes quando se transporta essa noção de legitimidade para as experiências não eleitorais. Como pensar o reconhecimento da autoridade (direito de falar por ou em nome de outros) e da atividade representativa (medida em que a representação aproxima-se dos interesses e preferências dos indivíduos) em um modelo que não possui controle institucionalizado e definição clara de quem são os constituintes?

Esse é um problema que Urbinati não enfrenta, pois o julgamento político exercido pelos atores sociais tem o papel de aproximação ou de simpatia entre suas ideias e decisões do Estado. Além disso, é preciso lembrar que a autora está tratando de uma sociedade aberta, livre e plural, na qual o julgamento político pode ser exercido por distintos atores e em diversas instâncias. "A igualdade política - como uma condição de legitimidade, um guia para o julgamento político e uma promessa a ser cumprida - é o ponto de referência em relação ao qual o processo político da representação democrática define seus objetivos, linguagem e projetos, e submete-se ao julgamento crítico dos cidadãos"' (Urbinati 2006, p. 6). Contudo, diante da desigualdade material, cultural e política que impede a manifestação autônoma dos indivíduos, é preciso considerar que o acesso aos mecanismos de influência da sociedade civil e o julgamento crítico dos cidadãos também é desigual. 
Miguel (2011) é um dos autores que denunciam esses limites. Para o autor, a atividade representativa é uma forma de exercício de poder, marcada pelo conflito e defesa de interesses, e, portanto, não pode prescindir da noção de autonomia. O desafio de uma representação democrática "é permitir que indíviduos e grupos capazes de definir autonomamente seus interesses se vejam representados por agentes com os quais tenham identidade e capacidade de interlocução" (idem, p. 28). Isso depende de condições sociais mais propícias à participação política e à autonomia dos indivíduos. $\mathrm{O}$ autor reconhece que não há saídas fáceis para esse dilema frente às desigualdades estruturais da sociedade capitalista e à ausência de universalização dos recursos materiais, informacionais e cognitivos que permitem seu desenvolvimento. Ademais, é crítico em relação às propostas atuais de representação da sociedade civil que retiram de cena os instrumentos institucionais de autorização e accountability. Em vez de focarmos no aprimoramento da democracia por meio da pluralidade de representantes da sociedade civil, que se apresentam como porta-vozes das necessidades e do bem-estar de outros sem controle institucionalizado, é preciso ampliar a participação no debate público e a dimensão da produção de interesses, levando em conta nessa produção os processos sociais que a constrangem.

A despeito da importância de seu alerta sobre as desigualdades que permeiam as relações Estado/sociedade, dois problemas dessa análise precisam ser apontados. Primeiro, com relação à noção de que atitudes não democráticas estão presentes no interior da sociedade civil. Essa é uma visão que já vem sendo disseminada entre os estudiosos da participação, que há muito tempo afastaram-se da visão idílica da sociedade como polo de virtudes (Dagnino 2002). O argumento nesse texto é que o reconhecimento das desigualdades não pode engessar a interpretação da representação da sociedade de modo a considerá-la como obrigatoriamente não democrática, como sugerido por Miguel (2011).

Em segundo lugar, deve-se questionar o veredito de Miguel (idem, p. 59) de que a representação da sociedade civil é uma falsa solução para o problema da exclusão e da autonomia. Tal conclusão parte de um diagnóstico precipitado sobre a ausência de preocupação com os mecanismos de autorização e prestação de contas, por parte dos autores que repensam a representação nos últimos anos. A noção de que todas as formas de representação que se pretendam democráticas devem passar pelo crivo do controle público encontra respaldo em grande parte da literatura. A diferença é que a legitimidade deixa de ser concebida como um fato, um atributo exclusivo do procedimento eleitoral e adquirida em um tempo específico. Nesse sentido, importa falar de processos de legitimação, nos quais a legitimidade é construída ao longo do tempo por meio do exame crítico da ação política. O sentido normativo da representação requer uma avaliação do processo representativo, de acordo com as características do relacionamento entre representantes e seus constituintes (Young 2000, p. 128). Como destaca Parkinson (2006, p. 25), a legitimidade é um ideal regulativo, não um ponto fixo em uma escala. Não obstante a ausência do procedimento de tipo eleitoral, seria possível sugerir processos de autorização menos formais e mais permanentes e manter a interlocução entre representante e representado? Nesta seção, serão discutidos os fundamentos da autorização, $a c$ countability e responsividade nas experiências de representação da sociedade civil, autoautorizadas (Urbinati \& Warren 2008) ou instituídas por métodos aleatórios (Brown 2006), que têm ênfase na influência e não no poder decisório dos atores sociais. 
Embora nas experiências informais da sociedade civil não seja possível que os indivíduos autorizem ou desautorizem diretamente o representante, elas podem expressar algum tipo de escolha. Esta é a defesa de Saward (2011), para quem o que distingue reivindicações democráticas das não democráticas é o grau em que a primeira demonstra um suficiente grau de "chosenness", no contexto de uma sociedade razoavelmente aberta. Em outras palavras, há uma evidência razoável de que constituintes de uma dada demanda representativa aceitam esse reivindicante como falando ou agindo por eles com consideração a certo conjunto de propostas (idem, p. 90).

Nesses casos, não há uma transferência formal de poder como a que ocorre na eleição ou na autorização recebida por conselheiros, associações e sindicatos. Tampouco a autorização expressa a manifestação de uma preferência que pode ser agregada. A autorização ou escolha deve ser buscada no reconhecimento público daqueles que reivindicam falar por indivíduos e grupos. O reconhecimento dos atores sociais como porta-vozes de temas e políticas, por exemplo, deve ser buscado na esfera pública discursiva, a partir da justificação pública desses representantes (Maia 2012). Nesse sentido, a autorização está intrinsecamente conectada com os mecanismos de prestação de contas. Como mostram Castiglione e Warren (2006), onde não há autorização, a accountability pode retrospectivamente e reflexivamente provê-la. Os autores destacam que a autorização pode se dar pela habilidade de atrair membros, convergência de propósitos, características descritivas ou visibilidade pública que promovem. O importante, nessa visão, é acentuar a interlocução que deve ser estabelecida com os representados, a fim de que estes possam reapropriar-se das demandas representativas ou escolher seus representantes.

Aliado a essa dimensão discursiva, nos espaços e atores que não são autoinstituídos, mas que são formados seja por iniciativa societal, seja estatal, como as pesquisas deliberativas ou júri de cidadãos, existe uma preocupação com o método de seleção dos representantes. Esses casos retomam métodos alternativos às eleições, como o sorteio ou a seleção randômica/amostral, com o objetivo de garantir a representatividade dos representantes (Brown 2006; Fishkin 2009; Parkinson 2006). Busca-se com isso que os representantes possam espelhar as características da população ou que sejam selecionados de forma proporcional ao tamanho do grupo e à intensidade desses interesses no resultado da política. Em razão da dificuldade de operacionalizar métodos mais inclusivos como o sorteio, esses experimentos têm, na prática, adotado amostragem por quotas. Assim, define-se algumas clivagens e/ou características socioeconômicas, de gênero ou étnicas, dos grupos que devem participar. As dificuldades em determinar os tipos de clivagens, bem como a natural sobreposição entre elas, são alguns dos limites desse tipo de autorização. Desse modo, assim como nos espaços autoinstituídos, a legitimidade da atividade representativa não deve estar divorciada do julgamento público.

III.2. Accountability não eleitoral

No que tange ao controle e ao julgamento público dos representantes da sociedade civil, Lavalle e Isunza Vera (2011) argumentam que, ao contrário da prestação de contas eleitoral, em que o ato do consentimento concentra tanto o momento de definição do representante, quanto os mecanismos de institucionalização do controle, a accountability da sociedade civil é dependente 
${ }^{8}$ Embora a sociedade civil não sofra sanção direta do voto, é possível pensar na sanção simbólica a que está sujeita quando age de maneira não responsável aos interesses aos quais diz representar, como a perda de credibilidade perante determinado público.

${ }^{9}$ A literatura sobre accountability avançou muito nos últimos anos nessas dimensões espaciais, destacando a transversalidade desses processos e a diversidade de atores envolvidos: estatais, societais coletivos e individuais. Neste trabalho, a dimensão vertical e horizontal é retomada apenas com o caráter ilustrativo mais geral das relações entre representante e representado e dos níveis de controle. de um processo que se desloca no tempo. Esse ponto leva a uma relação diacrônica do controle, em que a representação não deve ser medida pela quantidade de cidadãos que são capazes de participar nesses fóruns, mas pela natureza e qualidade da representação democrática obtida no processo participativo (Warren 2006, p. 4). Implica também um movimento constante de informação, argumentação e sanção entre representante e representado, para utilizar as três dimensões da accountability propostas por Schedler $(1999)^{8}$. Não obstante a leitura relacional da accountability, de Lavalle e Isunza Vera (2011), sugere-se, como empreendimento analítico, manter seus dois sentidos: vertical e horizontal ${ }^{9}$, tal qual formulação clássica de O'Donnell. Essa orientação pode ajudar na construção de estratégias metodológicas para avaliar a relação entre representantes e representados, bem como dos primeiros com outras agências e atores de representação e controle. É importante lembrar que a metáfora espacial aqui tem como referência os representantes da sociedade civil. Sendo assim, esses atores situam-se em posição horizontal em relação às entidades as quais fazem parte e ao leque de espaços e instituições societais que performam funções representativa e participativa.

Na sua dimensão vertical, o representante deve desenvolver formas de conexão com o representado, que será alvo das demandas e discursos por ele proferidos. No que se refere aos representantes autoautorizados e instituídos por métodos aleatórios, são muitas as fragilidades no controle da sociedade. Porém, não se pode esquecer que muitas vezes a manutenção ou sobrevivência desses atores depende do modo em que são capazes de responder às questões por eles defendidas. Sendo assim, os representantes da sociedade precisam, primeiramente, fomentar o debate público a fim de chamar a atenção da "opinião pública" sobre as questões que defendem e representam. Um bom exemplo de como contrabalançar a opinião que emerge no processo deliberativo com a recomendação direta da população foi utilizado na Assembleia de Cidadãos de British Columbia, responsável por discutir o sistema eleitoral (Brown 2006). Nessa experiência, as orientações que emergiram do fórum deliberativo foram alvo de um referendo, no qual a população teve o direito de expressar sua aprovação ou negação das propostas.

Em segundo lugar, não se pode esquecer do controle exercido pelos próprios representantes eleitos. Sem interlocução com os espaços formais de decisão, os atores sociais não serão capazes de influenciar a agenda pública. Nessa relação, a sociedade contribui tanto para a dimensão informativa quanto argumentativa do processo decisório institucionalizado, como apontou Rosanvallon (2009), além de estar sujeita à sanção simbólica dos atores estatais, caso estes não a reconheçam como legítima.

Por fim, é possível citar outras formas menos institucionalizadas e formais de controle, na qual a mídia é um exemplo interessante. Ela pode exercer um papel central na publicização dos atos dos representantes da sociedade civil, na geração de informação e obrigação de argumentação (Lavalle, Houtzager \& Castello 2006b).

No que se refere à dimensão horizontal, a interlocução dos representantes com suas bases e com outras instituições e espaços é ponto central. Nos casos em que o representante pertence a alguma entidade ou organização, essa pode servir como um lócus de prestação de contas. Apesar das críticas relativas à tendência de autonomização dos líderes de suas bases, como já expressava Michels (1982), Fox (2000, p. 11) argumenta que ela não é insuperável. A existência de mecanismos internos de accountability horizontal nas organizações 
civis, como instâncias intermediárias de participação, é um complemento crucial ao controle dos líderes, que não precisam lidar diretamente com membros ou indivíduos atomizados. Esses grupos ou instâncias de coordenação ajudam no compartilhamento de informações, na geração de alternativas e contrapropostas e na formação de potenciais líderes. Entender a complexidade dessas interações é essencial para não cairmos em uma avaliação determinista da impossibilidade da representação democrática dos atores sociais.

O controle também pode dar-se entre instituições e espaços de representação. Nessa perspectiva, a literatura recente da teoria deliberativa, focada na ideia de sistemas, propõe desterritorializar a representação democrática, a fim de percebê-la como dependente das distintas articulações que ocorrem na esfera pública e política (Parkinson 2003; 2006; Hendriks 2006). Desse modo, é preciso ir além da análise das instituições e processos individuais, a fim de examinar a interação do sistema como um todo (Mansbridge et al. 2012). Tendo em vista a compreensão da política como processo difícil de balancear diferentes interesses e visões dos cidadãos, essa literatura estabelece uma divisão do trabalho deliberativo, no qual é necessário combinar diferentes modos de representação/participação. A saída é avaliar em que medida deliberações que ocorrem em um local complementam ou promovem deslocamentos negativos em outros. Isso significa que a representação da sociedade, exercida em um espaço específico como um conselho de política, pode estar sujeita ao controle público de outros conselhos ou instituições. Ou, por exemplo, uma organização de defesa de direitos de mulheres está sujeita ao controle público exercido por uma rede mais ampla de organizações ligadas ao mesmo tema.

Essa mesma literatura é muito frutífera para avaliar as conexões verticais entre representante e representado. A teoria da deliberação sistêmica permite ao analista perceber em que medida representantes da sociedade civil estão sujeitos ao controle ou em interação com outros atores eleitos ou com a sociedade em geral. A questão a ser investigada é quando os discursos proferidos conseguem transitar de uma esfera para a outra e quais são as variáveis que explicam tal complementaridade ou deslocamento. Essa é uma pergunta ainda em aberto e alvo muito recente dos teóricos deliberativos, para a qual pode contribuir o desenvolvimento de pesquisas empíricas (Almeida 2012; Cunha \& Almeida 2013; Mendonça 2013; Faria, Petinelli \& Lins 2012).

III.3. Responsividade não-eleitoral

Em relação à responsividade, o principal problema é a diminuição da soberania popular diante da impossibilidade de influência direta sobre os mecanismos de representação societal. Desse modo, a legitimidade da fala ou do agir no lugar do representado de uma maneira sensível às suas demandas não está posta no consentimento direto dos indivíduos, mas na forma como se dá essa criação. Uma das propostas importantes nessa direção é aquela apresentada pela teoria feminista, que aposta na presença de certos grupos que compartilham determinadas perspectivas sociais para a defesa de seus interesses. De acordo com Young (2000), a noção de perspectivas sociais desloca a responsividade para o campo do compartilhamento de algumas características e para a similitude de condições de vivência. As perspectivas são importantes pontos de partida para a construção de interesses e não determinam em si o conteúdo da deliberação (idem). Como proposta que opera dentro da política eleitoral, a noção de perspectivas vêm sendo adotada, por exemplo, na política de cotas para mulheres e outros grupos excluídos ou na introdução de mecanismos alea- 
10 "They are, as such, activists promoting causes much more than delegates of constituents with defined preferences". Tradução da autora. tórios para preenchimento de cargos públicos (Miguel 2005). Já em relação à representação da sociedade civil, as perspectivas dão vazão à defesa da ampliação da pluralidade de vozes presentes nas esferas decisórias. Nessa direção, os mecanismos aleatórios são utilizados para composição de grupos deliberativos formados por uma amostra da população, que estudam problemas políticos e contribuem para decisões mais bem informadas. Esses grupos tradicionalmente marginalizados poderiam contribuir para dar visibilidade pública às demandas de seus "semelhantes" e para a sensibilização dos representantes eleitos, na medida em que compatilham as formas de ver o mundo de seus representados, vinculadas a certos padrões, socialmente estruturados, de experiências de vida (idem).

A representação por perspectivas é complementada por outras análises que destacam o papel da afinidade temática (Avritzer 2007). A responsividade pode ser gerada pela defesa de temas e de políticas que contam com ampla experiência dos atores, adquirida ao longo do seu histórico de participação e envolvimento com a política. O que as organizações da sociedade civil, movimentos sociais e indivíduos estão representando nesses casos é um discurso sobre direitos ou temas e não um conjunto específico de pessoas. Em uma linha próxima, Dryzek (2001) destaca a representação discursiva, na qual o papel dos atores é expressar discursos que são consistentes com a esfera pública e não expressos pela via eleitoral. O autor chega a propor a constituição de Câmaras Discursivas que agreguem representantes de diferentes discursos em um minipúblico deliberativo (Dryzek \& Niemeyer 2008).

É importante destacar que esses são elementos que podem ativar a responsividade ou contribuir para gerar discussões que caminhem para a formação dos interesses de quem se diz representar. Portanto, não se trata da defesa de interlocutores eloquentes que representam à revelia dos representados. $\mathrm{O}$ controle público é parte central da representação democrática, embora a forma como esse possa ser operacionalizado varie de uma experiência para a outra, como percebido acima.

Não obstante essas diferenças na operacionalização da accountability e responsividade, o que há de comum na teoria democrática contemporânea é o afastamento de uma noção de preferências dadas e posteriormente agregadas. A representação ganha uma dimensão sociológica de construção das preferências e mesmo do próprio representado, como parece mostrar claramente a ideia de Saward (2010). Na perspectiva do autor, é preciso olhar para as demandas de representação (representative claims), abordagem que destaca o lado atuante da representação e gera espaço para um trabalho normativo criativo na radicalização de nossas ideias sobre quem e o que pode valer como politicamente representativo. Nas palavras de Abers e Keck (2008b, p. 2) ${ }^{10}$, representantes da sociedade civil "são ativistas promovendo causas muito mais do que delegados de constituintes com preferências predefinidas".

Por fim, vale ressaltar que em todos esses casos há espaço para dominação ou construção não autônoma dos interesses, mas a avaliação do caráter democrático da representação da sociedade civil continua dependente de uma concepção processual e dinâmica. Não é determinada pela existência de uma fonte de legitimidade - a autorização - tampouco por meio da identificação de um constituinte específico. Além das possibilidades de controle aqui apresentadas, não se pode esquecer das particularidades dessa representação no sistema político como um todo. A crescente literatura sobre representação da sociedade civil, que acusa a presença de uma superposição de fronteiras entre Estado e 
sociedade, não tem dado devida importância aos distintos papéis dos atores coletivos (Fox 2000; Keck 2003). É importante lembrar que, geralmente, estamos diante de espaços informais de representação perante o poder político, responsável e autorizado a tomar as decisões. Em última instância, existe uma diferença na sua atuação que mantém a distinção clássica da representação que se exerce perante o poder, como era o caso dos corpos intermediários e do Parlamento na pré-modernidade, que não falavam diretamente em nome da sociedade, mas a representava diante do rei (Vieira \& Runciman 2008). A função principal é mobilizar e influenciar o poder público, no sentido de torná-lo mais accountable e responsivo aos interesses da sociedade.

Já nos espaços híbridos de formulação de políticas, além da representação perante o poder, há uma representação direta de temas, discursos e políticas pelos atores da sociedade civil. Mais do que apresentar demandas representativas, como coloca Saward (2010), há uma representação do poder, pois esses atores recebem algum tipo de autorização para tomar decisões em nome das pessoas que serão afetadas pela política. Desse modo, a próxima seção ocupase da avaliação da noção de autoridade que acompanha o conceito de representação, e da relação de autorização e accountability própria das ICGs no Brasil.

\section{As fontes de autoridade, autorização e accountability nas ICGs no Brasil}

O Brasil é um terreno fértil para a revisão teórica do conceito de representação política devido à variedade de experiências que vinculam Estado e sociedade no processo de formulação de políticas públicas. A composição das instituições de cogestão (ICGs) é variada, incluindo desde cidadãos voluntários até indivíduos membros de organizações civis (ONGs, associações de moradores, sindicatos, organizações trabalhistas, entidades filantrópicas etc.) e movimentos sociais. A classificação proposta por Avritzer (2009, pp. 69-74) distingue entre desenhos mais abertos em termos da inclusão de todos os cidadãos, nos quais o governo tem um papel de facilitador do processo deliberativo, como os orçamentos participativos (bottom-up design); passando por desenhos de compartilhamento de poder - conselhos de políticas - (power-sharing design), cuja participação dá-se em grande maioria por membros de organizações da sociedade civil eleitos ou indicados pelas mesmas e que compartilham poder de decisão com o governo; até desenhos de ratificação (ratification design), nos quais participantes de associações representativas podem aprovar ou rejeitar propostas do Estado, mas não têm poder de proposição. É possível ainda distinguir outras formas de interseção entre Estado e sociedade que não passam pela criação de espaços decisórios formais: a incorporação de ativistas de movimentos sociais em cargos governamentais, a formação de novos movimentos sociais a partir da interlocução entre ativistas dentro e fora do Estado e a cooperação entre burocracia pública e organizações não governamentais nas políticas públicas (Abers \& Von Büllow 2011; Lopez \& Abreu 2013).

Esta seção focará a representação dos atores sociais nas ICGs. Desse modo, pretende destacar as diferenças no processo de legitimação democrática dessas experiências quando confrontadas com os espaços ou atores informais de representação perante o poder público. A revisão da literatura aqui empreendida permite detectar, no mínimo, duas diferenças em relação à representação da sociedade civil apresentada na seção anterior, que revelam o estatuto teórico das experiências brasileiras no que tange à representação como processo ao mesmo tempo societal e institucional. A primeira refere-se à associação da 
esfera pública como o lócus privilegiado de atuação da sociedade civil. Para Habermas (2003), Cohen e Arato (1992), a sociedade opera fora das esferas de influência do Estado e do mercado. Os mecanismos de influência entre esfera pública e Estado não devem ameaçar a autonomia daquela. Essa é uma divisão que passou a ser contestada na literatura sobre democratização do Estado na América Latina, tendo em vista o crescente envolvimento da sociedade nos canais de formulação de políticas públicas e a flexibilização das fronteiras entre Estado e sociedade (Avritzer 2002; Keck 2003). Desse modo, o conceito espacializado de sociedade civil deixa de ser útil para teorizar a possibilidade de democratização e mudança social (Young 2000, p. 160). Em vez de pensar a diferenciação das esferas, Young (idem) propõe teorizar os diferentes tipos de atividades da sociedade e do Estado. Não obstante esse alerta, seu objetivo principal é pensar a esfera pública como espaço no qual a sociedade luta para influenciar os atores estatais, sem uma discussão aprofundada das consequências da vinculação das instituições e atores sociais às instituições estatais. Argumenta-se que a diferenciação entre estes dois polos da atividade política dentro e fora das instituições estatais - não é mais uma característica que define a priori a representação e a participação do Estado ou da sociedade, haja vista o trânsito dos atores nas diferentes esferas de deliberação. Mas a atenção ao local de atuação da sociedade continua como variável importante para distinção de suas atividades e do tipo de autoridade que mobiliza na interação com o Estado. Como se verá a seguir, apesar da flexibilização de fronteiras entre Estado e sociedade ter sido tematizada nas diferentes experiências de influência da sociedade civil, ela ganha proporções distintas no que tange à autoridade concedida aos atores sociais que compartilham poder decisório com os atores estatais.

A segunda diferença diz respeito ao processo de legitimação democrática. $\mathrm{O}$ encontro formal entre Estado e sociedade nas ICGs muda as características do processo de autorização e relacionamento entre representantes e representados. Mais do que um processo informal de escolha, dependente do julgamento público, essas instituições possuem regras de acesso que restringem ou ampliam a definição de quem é representante e, consequentemente, do público que será representado. Ademais, a seleção de atores sociais vinculados a organizações civis e em contato direto com o Estado na fase de formulação e fiscalização de políticas públicas introduz novas questões para a teorização da accountability e da responsividade.

\section{IV.1. Autoridade estatal vs. societal: diferenças entre as ICGs e as experiências informais}

A indefinição das fronteiras entre Estado e sociedade desloca a importância da análise espacial da sociedade civil, com foco exclusivo na esfera pública, para os diferentes tipos de atividade e autoridade mobilizada por esses atores na interação com as instituições estatais. Isso não significa dizer que a representação da sociedade iguale-se a do Estado, e vice-versa. Tampouco que a autoridade política seja igualmente distribuída. O fato de os atores sociais deterem autoridade no processo decisório não os colocam no mesmo patamar de ação do Estado, apenas aponta que ambos exercem voz dentro da instituição. $\mathrm{O}$ "tamanho" ou alcance da autoridade exercida por cidadãos é especificado em cada tipo de instituição de cogestão (Wampler 2012). Ademais, é inegável que o Estado é uma organização diferente e, portanto, a sociedade civil não pode ser vista como alternativa preferível ao Estado para a promoção da justiça social e da democracia. As instituições estatais têm capacidades únicas para co- 
ordenar, regular e administrar um contexto de larga escala, o qual uma democracia não pode funcionar bem (Young 2000, p. 156). Sua legitimidade deriva do consentimento dos indivíduos, o qual determina a capacidade de tomar decisões vinculantes que implicam a obediência dos cidadãos.

As atividades monopolistas do Estado e sua autoridade de jure, entretanto, são apenas parte da autoridade política necessária para o desenvolvimento das políticas públicas. A legitimidade política estatal, pensada de maneira substantiva concernente aos resultados justos, dependerá da maneira como coloca em prática seus projetos e ações. Para Abers e Keck (2013), não basta ter autoridade para agir, deve-se garantir que as coisas aconteçam e esta dimensão também envolve autoridade. Como outras organizações, o governo mobiliza capacidades organizacionais e implementa projetos, para os quais não é suficiente a autoridade formal. É preciso coordenar empregados, interagir em redes, realizar e participar de debates, elaborar planos, gerar e usar o conhecimento científico, ocupar cargos e construções, prover serviços, construir rodovias e hospitais, entre outras (idem). Todas essas atividades dependem do desenvolvimento de capacidades que não são exclusivas do Estado. Nesse ponto, as autoras chamam a atenção para a autoridade prática que pode ser construída tanto por atores estatais quanto societais. A autoridade prática envolve a mobilização e o desenvolvimento de capacidades e o reconhecimento público que permitem os atores tomar decisões e influenciar o comportamento de outras organizações e atores.

Na mesma linha processual de compreensão da construção da autoridade, Saward (2011) aponta que embora a tendência tenha sido cercear o conceito aos limites do Estado, é possível perceber o reconhecimento de que a reivindicação de autoridade é uma tarefa ativa e constante do representante e não um atributo exclusivo ou propriedade de determinado ator. Mesmo na definição weberiana de autoridade, que caminhou para a centralidade das instituições do Estado no exercício do poder legítimo, há uma dimensão sociológica da autoridade, que requer a percepção cultural dos indivíduos e a necessidade do representante apresentar razões convincentes nos termos aceitos por eles. Em "Política como vocação"", Weber (2004) define o Estado moderno como uma comunidade humana que reivindica, com sucesso, o monopólio do uso legítimo da força física dentro de um dado território. Fica claro, nessa definição, que o autor postula a autoridade legítima não como uma possessão do Estado, mas como uma prática de reivindicação. Nesse sentido, Saward mostra como a autoridade legítima demanda a interação com outras fontes que existem fora das estruturas estatais.

O reconhecimento de uma autoridade extraleitoral, exercida por atores sociais em sua influência junto ao Estado, deixa em aberto duas questões. Primeiro, qual é a diferença principal entre a autoridade estatal e societal. Segundo, como a esfera de atuação da sociedade interfere na avaliação que se faz da sua atividade representativa, especialmente, quando se compara as experiências informais, geralmente foco da literatura internacional, e as experiências que vinculam Estado e sociedade no processo de formulação de políticas públicas no Brasil. O debate apresentado por Saward (2011) sobre a compreensão do processo de constituição da autoridade legítima ajuda a esclarecer esses dois pontos.

Para diferenciação entre os tipos de autoridade prevalecentes na esfera pública, o autor adota a leitura de Friedman (1990) e sua distinção entre dois tipos de autoridade: "an authority" e "in authority". Pessoas e grupos represen- 
tantes da sociedade civil possuem "uma autoridade" baseada no conhecimento especializado, experiência ou expertise. Nesses casos, é o conteúdo do julgamento político que conta para avaliar sua autoridade. Já a autoridade dos atores do Estado deriva da posição que ocupam "in authority", sendo a fonte do julgamento que conta primariamente. Saward reconhece que as fronteiras entre a autoridade posicional e a da experiência e expertise são borradas e que essa superposição é importante para a análise da representação democrática (idem, p. 82). Por exemplo, ao ocupar uma posição central dentro de uma associação profissional ou ser chefe executivo de uma corporação ou de uma organização que formula políticas públicas, alguns indivíduos podem usufruir de graus de in-ness, à proporção que passam a ter acesso às estruturas de poder, responsáveis pela tomada de decisões.

Desse modo, é possível pensar as manifestações da sociedade civil a partir da noção de an authority e do conhecimento que mobilizam para defesa de suas demandas. Embora a separação entre in authority e an authority seja interessante para pensar a representação e a autoridade da sociedade civil, aqui serão propostas algumas adaptações. A referência à expertise ou especialização dos grupos e indivíduos representantes como fundamento ou elemento que mobiliza a autoridade precisa ser reinterpretada tanto para as experiências informais quanto formais de interação Estado/sociedade. Essa é uma conceituação que Saward retoma de Friedman. Para Friedman (1990), uma an authority é definida como uma autoridade de facto, no sentido que uma pessoa é capaz de obter obediência, fidelidade, influência ou crença de outros devido ao reconhecimento de suas qualidades pessoais. É uma autoridade que tem como premissa a desigualdade de conhecimento, não disponível a todas as pessoas, e está baseada no saber epistemológico (idem, pp. 82-83). Essa relação dá-se em um mundo de crenças compartilhadas e a partir do reconhecimento da desigualdade na capacidade dos homens entenderem essas crenças. Já a autoridade estatal, de jure, está baseada no acordo entre os homens no nível procedimental, sobre quem deve ser obedecido e quais falas contam como impositivas, sem avaliação dos méritos ou superioridade dos comandos.

Em que pese a incontestável desigualdade na relação política entre indivíduos que detêm oportunidades e recursos diferenciados, é difícil afirmar que a ação política restringe-se ao tipo de qualidades pessoais evocadas por Friedman. No que se refere às instituições de cogestão brasileiras, apesar de incluírem especialistas na temática e na política pública, como é o caso dos conselhos de políticas compostos por trabalhadores da área e prestadores de serviços, os saberes envolvidos muitas vezes estão dissociados de um conhecimento técnico ou de um saber epistemológico. Organizações da sociedade civil e indivíduos representativos nas ICGs compartilham ou adquirem um saber prático ou relacionado à vivência com o problema que os aproximam mais de uma comunidade de praticantes, como parece defender Avritzer (2007) e sua noção de legitimidade por afinidade. Para o autor, a afinidade legitima-se em uma identidade ou solidariedade parcial exercida anteriormente. Os indivíduos a desenvolvem ao longo do seu histórico de participação e envolvimento com a política. Desse modo, é preciso considerar esses elementos associados à trajetória política e participativa dos atores, que fogem de uma noção mais epistêmica da autoridade. Outrossim, a ação não é voltada para obter obediência, mas para a defesa de causas e temáticas, com as quais os atores se identificam.

Com relação à distinção entre as ICGs e os espaços informais, destaco que as oportunidades de tornar-se uma in authority estão legalmente institucionalizadas. Elas ultrapassam a transição eventual e não formalizada de atores para a 
esfera estatal, percebida por Saward (2011), ao ganharem reconhecimento legal dos representantes diretamente autorizados pelo voto. Se como atores sociais eles têm o poder negativo de influenciar as decisões estatais, quando investidos do poder legal de decisão pelo Estado, ganham um grau de in-ness, de autoridade posicional. Por autoridade posicional dos atores da sociedade civil, refiro-me ao exercício de voz e voto dentro das ICGs, o qual é especificado nos normativos que regulam o seu funcionamento a partir do poder deliberativo destes espaços. Nesses casos, a participação faz parte de um processo mais amplo de institucionalização da democracia brasileira. Mais do que apresentar demandas representativas, como coloca Saward (2010), há uma representação do poder, pois esses atores recebem autorização para tomar decisões em nome das pessoas que serão afetadas pela política.

Apesar dessas diferenças, o ponto central que se quer enfatizar é a conclusão de Saward (2011) de que a análise da representação democrática requer o reconhecimento da interdependência entre autoridade estatal e da sociedade civil. Nessa formulação, o autor avança em relação a Friedman (1990, p. 81), para o qual os dois tipos de autoridade são logicamente independentes. De acordo com Friedman, a autoridade legal e institucionalizada não é dependente da avaliação que se possa fazer sobre os méritos e deméritos das decisões. Já para Saward, a efetividade de uma in authority depende em parte do apoio e da relação que se estabelece com as demandas apresentadas na sociedade (an authority). Toda demanda democrática apresentada pelo Estado são em parte uma sedimentação de uma prévia e, em alguns casos, persistente demanda social. Nesse modelo, as ICGs podem ser interpretadas como parte do processo de sedimentação das demandas sociais, ao colocar em movimento a autoridade construída ao longo da experiência participativa e temática.

\section{IV.2. O processo de construção da legitimidade democrática nas ICGs}

No que tange ao processo de legitimação democrática, discutido na seção anterior para as experiências informais, as ICGs brasileiras também apresentam especificidades. Algumas questões relevantes para o debate teórico referem-se à forma como essas organizações têm acesso às estruturas do Estado e relacionam-se com a pluralidade representada. Ademais, existem diversas formas de representação da sociedade civil, nas quais o grau em que esses atores exercem o poder deliberativo, leia-se, discursivo e decisório, também é variado. Em alguns casos, as decisões emanadas de um conselho de saúde, por exemplo, são vinculativas, no sentido de que obrigam o governo a cumpri-las. Esse poder decisório é conferido pelas leis que regulamentam seu funcionamento, o que não significa, na prática, que as decisões são necessariamente implementadas pelos atores estatais. Em outros, a deliberação apenas expressa uma orientação e diretriz que caberá avaliação pelo poder público.

Em relação à forma de acesso, existe um tipo de autorização e de reconhecimento do poder público desses atores como legítimos representantes. As ICGs adotam um processo de escolha que tem origem entre os atores da sociedade civil e é decidida frequentemente no interior de associações civis (Avritzer 2007). Alguns espaços, como conselhos de políticas, elegem seus representantes entre um público restrito, que possui vinculação com entidades e organizações civis, ou indicam seus membros. Em alguns momentos, tais organizações já estão delimitadas por lei ou regimento interno. Em outros, o processo é renovado a cada mandato. Nos OPs, há eleição entre os participantes para os delegados, responsáveis pela fiscalização e acompanhamento das 
obras. Já comitês de bacia também adotam eleições de entidades, mas geralmente há requisitos legais e temáticos que precisam ser preenchidos para ter o direito de participar. Avaliar tais particularidades e a possibilidade ou não de renovação das lideranças, bem como a existência de disputa dos distintos interesses, opiniões e perspectivas, é crucial para a qualificação dessa representação como democrática.

A presença de um processo de escolha tem implicações diretas na definição do representado. Apesar de o conceito de representação, como processo, apostar na construção e na indefinição do representado, é possível dizer que, nas ICGs, essa construção responde em parte às características e objetivos das instituições. Existe uma interdependência entre as questões, quem e o que se representa, na medida em que a definição prévia de qual é o público que deve compor cada ICG, em certa medida influencia o que será representado - tipo de demandas, afinidades e perspectivas que estarão presentes. Tal definição está baseada nas características das políticas públicas que são objeto de deliberação nos espaços de cogestão. Nos atos normativos que regulamentam, por exemplo, a composição de conselhos de saúde, a definição do número de delegados de alguns OPs e a composição de comitês de bacia hidrográfica, há uma preocupação de incluir representantes das diversas clivagens sociais da área de política. Essa definição nem sempre é fácil, devido à transversalidade e à complexidade das questões envolvidas.

Considerando que a representação demanda algo mais amplo e contínuo do que a escolha ou autorização dos representantes, uma última questão que esse artigo traz à baila é se existe uma distinção na forma em que as ICGs relacionam-se com a pluralidade representada. Desse modo, parte do pressuposto que a existência de uma autoridade que se forma na prática deliberativa e participativa depende do reconhecimento do representado a fim de efetivar-se democraticamente. Da mesma forma que a autoridade do Estado não é independente do conteúdo da representação, tampouco do reconhecimento de sua autoridade por parte da sociedade, as ICGs precisam estar sujeitas ao julgamento público sobre a pertinência de suas propostas.

Embora não prestem contas a um constituinte individual, atores coletivos oferecem um tipo de prestação de contas discursiva ao público, uma forma de accountability que pode complementar o controle eleitoral. A prestação de contas pública pode ser efetivada por meio de acordos que reflitam a opinião pública refinada por meio do processo de debate. Além da prestação de contas discursiva, é possível vislumbrar um tipo de controle direto da sociedade, quando se demanda a um conselho de saúde, por exemplo, uma atuação em determinado problema nos serviços prestados no município. Ou seja, os representantes das ICGs podem beneficiar-se de uma relativa proximidade com os "afetados" e da experiência acumulada ao longo do tempo, seja por fazer parte de uma determinada policy community, seja pelo senso de identidade e sentimento de pertencimento e afinidade com a temática a ser deliberada (Avritzer 2007), para a construção do processo deliberativo.

A importância do reconhecimento, por parte do representado, da autoridade exercida pelos atores sociais nas instituições de cogestão não deve se afastar, contudo, de uma proposta relacional de prestação de contas e responsividade. Um modelo ou ideal de representação em que grupos nomeados agem no interesse de públicos predefinidos falha ao não levar em conta as relações que se desenvolvem entre os indivíduos que são escolhidos pelas associações e pelas instituições governamentais para participar neles. Tal modelo deixa escapar 
sua criatividade, congelando as relações em papéis preordenados, e supõe uma possível homogeneidade de posições entre organizações da sociedade civil que, além de impraticável, é indesejável (Abers \& Keck 2008a). Se o que ocorre nas ICGs é um processo de interação inovadora entre atores com diferentes pontos de vista e diferentes recursos, e se o resultado pode ser não só a redefinição de compreensões, mas também de capacidades reais, então quem ou o que está sendo representado nesses espaços está sempre em movimento (idem).

As possibilidades de construção de um processo deliberativo não dispensam a necessidade de desenvolvimento de canais permanentes de interação, como meios de divulgação mais amplos de suas ações (internet, jornal, rádio e televisão), tampouco maior interlocução com seus membros. Mais do que dupla face, como apostam Lavalle e Isunza Vera (2011), defende-se que a $a c$ countability é um processo que deve desenvolver-se de maneira relacional em diferentes níveis. Manifestações de protesto e ativismo dos indivíduos podem, por exemplo, impulsionar tanto diretamente o Estado como agências de controle e sociedade organizada, de modo a exigir explicações e justificações. Ao mesmo tempo, a sociedade civil, dentro das instituições, pode servir ela própria de agência de controle forçando o Estado a informar ou deliberando sobre o cumprimento de determinada orientação política. Situar as ICGs nessa rede ampla pode ajudar a compreender suas possibilidades e limites no processo de prestação de contas e responsividade.

Por fim, não se pode esquecer que a efetividade da autoridade dos atores sociais não está dissociada do seu reconhecimento pelo Estado. Tal reconhecimento deve extrapolar a abertura formal de espaços de deliberação. Em suma, os governos precisam estar significativamente envolvidos a fim de fazer com que as instituições funcionem bem. Isso demanda comprometimento políticoideológico dos atores responsáveis por sua criação, no sentido de apoiar e incentivar a participação, e capacidade de organização e pressão da sociedade (Dagnino 2002). Além dos incentivos e recursos políticos, não se pode esquecer da coordenação e capacidade de implementação por parte das agências estatais. As autoridades governamentais devem prestar o apoio administrativo para assegurar que os membros de conselhos, comitês, orçamentos participativos, por exemplo, tenham informações de boa qualidade. Talvez ainda mais importante, atores governamentais devem modificar o conteúdo e o processo por meio dos quais as políticas são implementadas para responder às demandas políticas dos membros das ICGs. Quando tais atores procuram trabalhar com os membros do conselho e funcionários governamentais estão habituados a trabalhar em estreita colaboração com a sociedade, há uma probabilidade maior de que, em conjunto, contribuam para o programa político (Wampler 2011, p. 155).

\section{Conclusões}

A compreensão da representação na teoria política contemporânea, ao mesmo tempo em que amplia as possibilidades de aplicação do conceito às experiências de representação de facto, coloca uma série de desafios para a justificação de sua legitimidade. Como avaliar a legitimidade das "reivindicações representativas" (Saward 2011) e como interpretar a autoridade exercida pela sociedade civil, são algumas questões que este trabalho buscou responder. 
Antes de discutir, porém, os fundamentos da legitimidade da representação, apresentou-se aqui uma proposta de redefinição do conceito. Propôs-se trazer para o centro do debate duas características da representação que estão presentes nos teóricos que repensam o conceito, a saber, a ideia de que a representação é um processo e uma construção. Representar é uma atividade que se desloca continuamente no tempo e no espaço; envolve distintos atores e arenas, do Estado e da sociedade; depende da interação contínua e ao longo do tempo entre representantes e representados e para a qual não há uma definição prévia do que é representado e de quem representa.

A partir dessa noção ampliada da atividade representativa, os fundamentos da legitimidade democrática da representação são direcionados para o processo, não definidos com base em um atributo de determinado procedimento ou ação. Nesse sentido, importa falar de processos de legitimação, nos quais a legitimidade é construída ao longo do tempo por meio do exame crítico da ação política. O trabalho apresentou as diferenças no processo de autorização e as dificuldades envolvidas na falta de controle institucionalizado e de uma definição clara de quem são os constituintes. Propôs uma leitura relacional da prestação de contas, na qual o controle pode desenvolver-se tanto verticalmente, no diálogo com os representados e com o próprio Estado, quanto horizontalmente, a partir de mecanismos internos de relação entre associações e suas lideranças, bem como entre instituições. Em vez de focar o relacionamento atomizado entre representantes e seus constituintes individuais, a literatura sistêmica da deliberação, presente em autores como Parkinson e Mansbridge (2012), sugere olhar para o sistema como um todo. Assim, as pesquisas empíricas na área precisam começar a investigar em que medida e quando as distintas arenas deliberativas conectam-se, quais fatores contribuem para a complementaridade das ações e que tipo de impactos promovem, no sentido da produção de decisões mais plurais e representativas dos distintos interesses. Igualmente, a responsividade tem sido tematizada a partir do compartilhamento de perspectivas sociais, presença de afinidade ou de discursos que sejam consistentes com a esfera pública. Não obstante os limites e fluidez do processo de legitimação da sociedade civil, não se pode esquecer das particularidades dessa representação no sistema político como um todo. Sua função principal é mobilizar e influenciar o poder público, no sentido de torná-lo mais accountable e responsivo aos interesses da sociedade.

Um último movimento do artigo foi olhar para o universo das instituições de cogestão, tendo em vista suas diferenças em relação à representação mais informal dos atores sociais, geralmente foco da literatura internacional. Para além de representarem de facto, essas instituições são representantes de jure, e compõem a arquitetura institucional da democracia brasileira (Lavalle 2011). Duas diferenças centrais foram destacadas: uma concernente ao impacto da interseção da sociedade com o Estado no processo decisório, e outra relativa ao processo de legitimação democrática.

Em relação à primeira, as ICGs colocam em evidência a flexibilização de fronteiras entre Estado e sociedade, responsável por obscurecer a tradicional diferenciação espacial entre esses dois polos. Nessa direção, ganha ênfase os distintos tipos de atividade e autoridade mobilizada pela sociedade na interação com o Estado. A principal distinção entre autoridade estatal e societal refere-se à importância da fonte e do conteúdo de julgamento político, respectivamente. Enquanto os atores estatais legitimam-se pela posição que ocupam e pelo consentimento, pessoas e grupos representantes da sociedade civil possuem "uma autoridade" baseada no conhecimento especializado, ex- 
periência ou expertise. No caso das ICGs brasileiras é preciso dar maior ênfase ao saber construído ao longo da vivência do que a uma expertise técnica ou especializada. Quanto à diferenciação com as experiências informais, o local de atuação tem impacto na autoridade exercida pelos atores sociais, uma vez que seu trânsito nos espaços estatais não é apenas eventual e informal. Os atores coletivos que compõem as ICGs ganham uma autoridade posicional, quando investidos do poder legal de decisão e deliberação pelo Estado. Ou seja, sua autoridade não é apenas um atributo de sua ação, mas também da fonte que emana tal autoridade, a saber, o lócus que ocupam dentro do processo de formulação de políticas públicas.

A segunda diferença refere-se ao processo de legitimação. A presença de autorização, mesmo que limitada, tem implicações na definição de quem representa e do que é representado. Há uma mútua dependência entre essas dimensões, na medida em que a forma de acesso às ICGs influencia diretamente $o$ que se representa - tipo de demandas, afinidades e perspectivas que estarão presentes. A avaliação do relacionamento entre representantes e a pluralidade representada também apresenta especificidades. Apesar da semelhança na proposta relacional da prestação de contas, as ICGs permitem relativa proximidade ou identificação dos "afetados" pela política. Ademais, sua institucionalização pode contribuir para o reconhecimento das ações pelo público.

Por fim, o trabalho enfatizou a importância do reconhecimento do Estado das demandas de representação da sociedade civil. O acúmulo de estudos sobre as ICGs tem mostrado que embora o Estado brasileiro frequentemente promova momentos e crie espaços de relação com a sociedade, nem sempre esse reconhecimento tem ultrapassado as barreiras da simples formalidade. Investigar empiricamente o processo de legitimação dessas experiências é tarefa dos estudiosos sobre o tema. Aqui, o objetivo foi apontar novos rumos teóricos para a compreensão da relação Estado e sociedade, cuja característica central parece ser a constante mutação.

Debora Rezende de Almeida (deborarezende.almeida@gmail.com) é doutora em Ciência Política pela Universidade Federal de Minas Gerais (UFMG) e Professora de Ciência Política na Universidade de Brasília (UnB).

\section{Referências}

Abers, R.; Keck, M.E. 2008a. Representando a diversidade: Estado, sociedade e "relações fecundas" nos conselhos gestores. Caderno CRH, 21(52), pp. 99-112.

2008b. The Collective Constitution of Representative Authority in Brazilian River Basin Committees. In Conference Rethinking Representation: A North South Dialogue. Bellagio.

. 2013. Practical Authority: Agency and institutional change in Brazilian water politics. Oxford: Oxford University Press.

Abers, R.; Von Büllow, M. 2011. Movimentos sociais na teoria e na prática: como estudar o ativismo através da fronteira entre Estado e sociedade? Sociologias,13(28), pp. 52-84.

Almeida, D.R. 2012. Representação política e conferências: os desafios da inclusão da pluralidade. Textos para Discussão, IPEA, 1750, pp. 1-46.

Ankersmit, F.R. 2002. Political Representation. Stanford: Stanford University Press.

Araujo, C. 2009. Representação, soberania e a questão democrática.Revista Brasileira de Ciência Política, 1, pp. 47-61.

Avritzer, L.2002. Democracy and the Public Space in Latin America. New Jersey: Princeton University Press.

2007. Sociedade civil, instituições participativas e representação: da autorização à legitimidade da ação. Dados, 50(3), pp. 443-464.

. 2009. Participatory Institutions in Democratic Brazil. Washington (D.C.): Woodrow Wilson Center. 
2012. Democracy Beyond Aggregation: The participatory dimension of public deliberation. Journal of Public Deliberation, $8(2)$, pp. 1-20.

Bohman, J. 2012. Representation in the Deliberative System. InJ. Parkinson; J. Mansbridge, eds. Deliberative Systems: Deliberative democracy at the large scale. Cambridge: Cambridge University Press.

Brown, M.B. 2006. Survey Article: Citizen panels and the concept of representation. The Journal of Political Philosophy, 14 (2), pp. 203-225.

Castiglione, D.; Warren, M.E. 2006. Rethinking Democratic Representation: Eight theoretical issues. InRethinking Democratic Representation Workshop. Columbia.

Cohen, J.L.; Arato, A. 1992. Civil Society and Political Theory. Cambridge (Ma): MIT.

Cunha, E.S.; Almeida, D.R. 2013. Sociedade civil e representação nas arenas deliberativas da Assistência Social no Brasil. In LASA's $31^{\text {th }}$ International Congress. Washington, D.C.

Dagnino, E., ed. 2002. Sociedade civil e espaços públicos no Brasil. São Paulo: Paz e Terra. 2004. Anos 90: política e sociedade no Brasil. São Paulo: Brasiliense.

Dryzek, J. 2000. Deliberation Democracy and Beyond: Liberals, Critics, and Contestations Oxford: Oxford University Press. 2001. Legitimacy and Economy in Deliberative Democracy. Political Theory, 29(5), pp. 651-669.

Dryzek, J.S.; Niemeyer, S. 2008. Discursive Representation. American Political Science Review, 102(4), pp. $481-483$.

Faria, A.M.T. 2010. Do social e do político: teorias da representação política. In $34^{\circ}$ Encontro Anual da Anpocs. Caxambu (MG).

Faria, C.F.; Petinelli, V.; Lins, I.L. 2012. Conferências de políticas públicas: um sistema integrado de participação e deliberação? Revista Brasileira de Ciência Política, 7, pp. 249-284.

Fishkin, J. 2009. When the People Speak: Deliberative democracy and public consultation. Oxford: Oxford University Press.

Fox, J. 2000. Civil Society and Political Accountability: Propositions for discussion. In Conference on Institutions, Accountability and Democratic Governance in Latin America. Notre Dame.

Friedman, R.B. 1990. On the Concept of Authority in Political Philosophy. InJ. Raz, ed. Authority. New York: New York University Press.

Habermas, J. 2003. Direito e democracia: entre facticidade e validade. Rio de Janeiro: Tempo Brasileiro.

Hendriks, C. 2006. Integrated Deliberation: Reconciling civil society's dual role in deliberative democracy. Political Studies, 54(3), pp. 486-508.

Keck, M.E. 2003. Governance Regimes and the Politics of Discursive Representation. InN. Piper; A. Uhlin, eds. Transnational Activism in Asia: Problems of power and democracy. London: Routledge.

Knights, M. 2009. Participation and Representation Before Democracy: Petitions and addresses in premodern Britain. InI. Shapiro; S.C. Stokes; E.J. Woods; A.S. Kirschner, eds. Political Representation. Cambridge: Cambridge University Press.

Lavalle, A.G. 2011. Após a participação: nota introdutória. Lua Nova, 84, pp. 13-23.

Lavalle, A.G.; Araujo, C. 2008. O debate sobre a representação política no Brasil: nota introdutória. Caderno CRH, 21(52), pp. 9-12.

Lavalle, A.G; Houtzager, P.; Castello, G. 2006a. Democracia, pluralização da representação e sociedade civil. Lua Nova, 67, pp. 49-103.

2006b. Representação política e organizações civis: novas instâncias de mediação e os desafios da legitimidade. Revista Brasileira de Ciências Sociais, 21(60), pp. 44-66.

Lavalle, A.G.; Isunza Vera, E. 2011. A trama da crítica democrática: da participação à representação e à accountability. Lua Nova, 84, pp. 95-139.

Lopez, F.G.; Abreu, R.F. 2013. As ONGs e as políticas públicas no Brasil: o ponto de vista de gestores federais. In Congress of the Latin American Studies Association. Washington, D.C.

Loureiro, M.R. 2009. Interpretações contemporâneas da representação. Revista Brasileira de Ciência Política, 1, pp. 63-93.

Lüchmann, L.H.H. 2008. Participação e representação nos conselhos gestores e no orçamento participativo. Caderno CRH, 21(52), pp. 87-97. 2011. Associações, participação e representação: combinações e tensões. Lua Nova, 84, pp. 141-174.

Maia, R. 2012. Representação política e atores cívicos: entre a imediaticidade da experiência e discursos de justificação. Revista Brasileira de Ciências Sociais,27(78), pp. 97-112.

Manin, B. 2007. The Principles of Representative Government. Cambridge: Cambridge University Press.

Mansbridge, J. 2003. Rethinking Representation. American Political Science Review, 97(4), pp. 515-527.

Mansbridge, J.; Bohman, J.; Chambers, S.; Christiano, T.; Fung, A.; Parkinson, J.; Thompson, D.F.; Warren, M.E. 2012. A Systemic Approach to Deliberative Democracy. InJ. Parkinson; J. Mansbridge, eds. Deliberative Systems: Deliberative democracy at the large scale. Cambridge: Cambridge University Press.

Mendonça, R.F. 2013. The Conditions and Dilemmas of Deliberative Systems. In APSA Annual Meeting. Chicago.

Michels, R. 1982. Sociologia dos partidos políticos. Brasília: UNB.

Miguel, L.F. 2005. Impasses da accountability: dilemas e alternativas da representação política. Revista de Sociologia e Política, 25, pp. 25-38. 
2011. Representação democrática: autonomia e interesse ou identidade e advocacy. Lua Nova, 84, pp. 353-364.

Parkinson, J. 2003. Legitimacy Problems in Deliberative Democracy. Political Studies,51(1), pp. 180-196. 2006. Deliberative in the Real World: Problems of legitimacy in deliberative democracy. New York: Oxford University Press.

Parkinson, J.; Mansbridge, J., eds. Deliberative Systems: Deliberative Democracy at the Large Scale. Cambridge: Cambridge University Press.

Pitkin, H.F. 1967. The Concept of Representation. Berkeley: University of California Press.

Przeworski, A.; Stokes, S.; Manin, B., eds. 1999. Democratic Accountability and Representation. Cambridge: Cambridge University Press.

Rosanvallon, P. 2006. Democracy: Past and Future. New York: Columbia University Press. 2008. Counter-Democracy: Policy in an age of distrust. New York: Cambridge University Press. 2009. La legitimidad democrática: imparcialidad, reflexividad, proximidad. Buenos Aires: Manantial.

Saward, M. 2006. The Representative Claim. Contemporary Political Theory,5, pp. 297-318. 2008. Representation and Democracy: Revisions and possibilities. Sociology Compass, 2(3), pp. 1000-1013. 2010. The Representative Claim. Oxford: Oxford University Press.

2011. The Wider Canvas: Representation and democracy in state and society. In S. Alonso; J. Keane; W. Merkel, eds. The Future of Representative Democracy. Cambridge: Cambridge University Press.

Schedler, A. 1999. Conceptualizing Accountability. InA. Schedler; L. Diamond; M.F. Plattner, eds. The Self-Restraining State: Power and accoutability in new democracies. London: Lynne Riemer.

Skinner, Q. 2005. Hobbes on Representation. European Journal of Philosophy, 13(2), pp. 155-184.

Urbinati, N. 2006. Representative Democracy.Chicago: University of Chicago Press. 2010. Unpolitical Democracy. Political Theory, 38(1), pp. 65-92.

2011. Representative Democracy and Its Critics. In S. Alonso; J. Keane; W. Merkel, eds. The Future of Representative Democracy. Cambridge: Cambridge University Press.

Urbinati, N.; Warren, M. E. 2008. The Concept of Representation in Contemporary Democratic Theory. Annual Review of Political Science, 11, pp. 387-412.

Vieira, M.B.; Runciman, D. 2008. Representation. Cambridge: Polity Press.

Wampler, B. 2011. Instituições participativas como "enxertos" na estrutura do Estado: a importância de contextos, atores e suas estratégias. InR.R.C. Pires, ed. A efetividade das instituições participativas no Brasil: perspectivas, abordagens e estratégias de avaliação. Brasília: IPEA.

2012. Participation, Representation, and Social Justice: Using participatory governance to transform representative democracy. Polity,44(4), pp. 666-682.

Warren, M.E. 2006. Citizen representatives. Prepared for Designing Democratic Renewal. Digit.

Weber, M. 2004. A política como vocação. In___. Ciência e política: duas vocações. São Paulo: Cultrix.

Young, I.M. 2000. Inclusion and Democracy.Oxford: Oxford University Press.

\section{ABSTRACT}

The concept of political representation has undergone a major overhaul in contemporary political theory motivated by the empirical observation of the role of civil society as a political representative. The acknowledgment of representation in societal field has imposed new challenges to democratic theory, some of them will be addressed in this paper. First, the article proposes to rethink the concept of political representation, based on two main ideas, namely, the representation is a process and it is a construction. Second, in order to understand the democratizing potentials of these transformations, this paper reinterprets the criteria of legitimacy of representation. It suggests that legitimacy is built during the representation and not only achieved by electoral authorization. This requires neither we abandon the tension between representative and represented, nor we leave the authorization mechanisms and accountability. But to rethink them from a continuous and distinct process among the varied examples of representation of society. Finally, the article argues that the practices of civil society representation in public policies co-management institutions in Brazil bring distinctive contribution to the theory of representation. These institutions put emphasis on the importance of distinguishing between the actors of the State and society from a consideration to the representative activity and authority mobilized, and not primarily from their sphere of action. Different from informal spaces of social influence, the collective actors that participate in these institutions gain a positional authority, when invested with legal power of deliberation and decision by the State. Moreover, the comanagement institutions introduces new elements to evaluate the process of authorization, accountability and responsiveness, not thematized in the international literature.

KEYWORDS: political theory; representation; democracy; legitimacy; co-management institutions. 